\title{
Sources of Academic Stress among Undergraduates at University of Ilorin, Ilorin, Nigeria
}

\author{
Lateef Omotosho Adegboyega
}

\begin{abstract}
The academic challenges faced by university students are enormous and emerge from various sources. It is in the light of this that this study investigated the sources of academic stress among undergraduates at the University of Ilorin, Nigeria. Demographic variables of gender, age and mode of entry were considered. A descriptive survey design was adopted. A sample of 300 students was randomly selected across the faculties. A research question was raised and three null hypotheses were postulated respectively to guide the study. Data were collected using a researcher-designed questionnaire entitled "Sources of Academic Stress Questionnaire" (SASQ). Data analysis was done using percentages, mean and t-test. The findings of this study revealed that University of Ilorin undergraduates are exposed to different sources of academic stress which include academic overloads, fear of failure and acclimatizing to academic expectations. The findings also showed that there was no significant difference in the sources of academic stress among undergraduates at the University of Ilorin based on gender and age while there was a significant difference in the sources of academic stress among undergraduates based on mode of entry. Based on the findings of this study, it was recommended that orientation programs should be made compulsory for all newly admitted students and academic development programs created for returnees at faculties and departmental levels.
\end{abstract}

Key words: sources, academic stress, undergraduates, University of Ilorin

Lateef Omotosho Adegboyega, Ph.D., a Lecturer in the Department of Counsellor Education, University of Ilorin, Nigeria obtained his Doctor of Philosophy (2017) in Educational Guidance and Counselling from the University of Ilorin, Nigeria. He is a registered teacher with the Teachers' Registration Council of Nigeria (TRCN) and is a member of the Counselling Association of Nigeria and of the Association of Professional Counsellors in Nigeria. He is also a Licensed Professional Counsellor of Nigeria (LPCN) and Certified Counsellor of Nigeria (CCN). Recent publications include: Adegoyega, L.O. \& Jacob, O.A. (2017). Causes of Premarital Sex as Expressed by Youth in Yagba West, Kogi State, Nigeria. Anatolian Journal of Education, 2(2), 8-20; Adegboyega, L.O. (2018). Influence of Achievement Motivation on Nigerian Youths' Attitude Towards Examination. International Journal of Instruction, 11 (1), 77-88; and Adegboyega, L.O. (2019). Influence of Social Media on Sexual Behaviour of Youth in Kwara State: Implications for Counselling Practice. Canadian Journal of Family and Youth, 11(1), 85-103. 


\section{Introduction}

Education is a life-long process that offers interpretation by purpose, type and level. It is a means of socializing people into the community, for upholding customs and traditions as well as for the modification or changing of same in conformity with existing ideologies, ideological expansion or reformation. Education in Nigeria is of three stages - nine years of basic education, three years of senior secondary education and four years of higher/tertiary education which refers to a 9-3-4 system of education (National Policy on Education, 2013).

Higher education is post-secondary education (or study beyond the level of postsecondary education) where a degree, diploma, or certificate is awarded at the end of study. Higher education builds on the level of competence, knowledge and skills normally acquired in secondary education. The exact definition of this level of higher education, institution, or program, varies from one country to another.

Consequently, the concept of a higher educational institution may also vary. For example, in some countries such as the United States, Canada, and Nigeria, teacher education is considered to be a field of higher education. In some countries, it is considered to be part of post-secondary education, but not part of higher education. The Association of African Universities (AAU) Working Group on Higher Education recommends that higher education should include tertiary educational institutions other than universities. Higher education in Nigeria comprises monotechinics, polytechnics and universities (NPE, 2013).

Stress has become an important subject in the academic sphere as well as in Nigerian culture. Many researchers in the field of behavioural science have carried out extensive research on stress and its consequences and have concluded that the subject needs more emphasis and concentration (Rees \& Redfern, 2000). Stress in academic institutions can have both positive and negative consequences if not well managed (Smith, 2002). However, it is important to society that students should learn and obtain essential knowledge and skills in order to help them contribute positively to the development of the nation.

Nonetheless, university students suffer from different kinds of academic stressors during their educational experiences. The idea for this research project came by observing students' interactions during the teaching/learning process, by the record unit in college counseling and by the number of students who were looking for help. It is hoped that the results of this particular research project attracts the attention of officials at the University of Ilorin and helps them to control the stress factors experienced by students. The results of this research could also assist in developing preferable methods and practices which would enable students to cope with stressors during their years of study.

University students are at a high risk for increased stress. Demanding academic pressures and limited social and personal time can add to the normal stresses of life and begin to have a negative effect on an individual. Stress is a common element in the lives of every individual, regardless of race or cultural background (Garret, 2001). Over the past few decades, there has been significant investigation related to the issues of stress and the management of stress (Dziegielwski, Turnage, \& Roest-Marti, 2004). In addition, college students have been shown to possess a unique set of stressors which can affect their daily experiences (Garret, 2001).

Campbell (2006) defined stress as the adverse reaction people have to excessive pressure or other types of demands placed on them. Stress occurs when an individual is confronted by a situation that they perceive as overwhelming and that they cannot cope with. Academic stress among students has long been researched and researchers have identified various stressors which includes having too many assignments to complete, competition with 
other students, failures, lack of pocket money ${ }^{1}$, poor relationships with other students or lecturers, or family, and problems at home. Institutional (university) level stressors include overcrowded lecture halls ${ }^{2}$, the semester system, and inadequate resources to perform academic work.

Moreover, university students have a unique cluster of stressful experiences or stressors (Garret, 2001). According to Misra and McKean (2000), there are several explanations for increased stress levels among college students. First, students have to make significant adjustments to college life. Second, because of the pressure of studies, there is strain placed on interpersonal relationships. Third, housing arrangements and changes in lifestyle contribute to stress experienced by university students. In addition, students in college experience stress related to academic requirements, support systems, and ineffective coping skills. Whereas these factors have been found to be responsible for stress, it is worth noting that in order to minimize stress among students, University administrators must develop appropriate strategies that will enable them to detect, in advance, the symptoms and causes of stress and external environments.

Moreover, institutions worldwide have not taken serious steps to understand or investigate the health of students. This could be attributed to the fact that students who stay at the university do so only for a short period of time and therefore their stress has little direct impact on the activities or operations of the institution. Another reason why little has been done on students' stress could be due to the fact that students' presence in the institution has no direct relationship to the quality of education they obtain. Finlayson (2003) reported that unless the university puts appropriate measures into place that take care of, or place emphasis on the well-being of students, student health may compromise the quality of education they are supposed to acquire. Gibbons and Gibbons (2007) and McCarty et.al. (2007) have carried out extensive research on stress and found that stress is associated with how an individual appraises situations and the coping strategies that is adopted.

\section{Problem}

Student performance at institutions of higher learning is generally attributable to a range of diverse reasons, which are both intrinsic and extrinsic in nature. At the University of Ilorin, the standards of students are checked regularly before and after every examination. Indications from much of the previous research in this area seems to suggest that the cause for most deviations from the agreed upon standard is attributable to stress.

Some students face problems associated with feelings of inferiority. Timemanagement, self-discipline and independence are some of the traits most of them battle to master. Academic commitments, financial pressures, and the lack of time management skills have resulted in many university students experiencing intense stress at predictable times during each semester. Even though such student problems are so widespread, the issue of academic stress among university students has become a topic of interest for few researchers today. As such, this study is an important and unique one as it investigates the various sources of academic stress experienced among undergraduates at the University of Ilorin.

\footnotetext{
${ }^{1}$ Fairbrother \& Warn (2003).

2 Ongori (2007).
} 


\section{Research Question}

1. What are the sources of academic stress among undergraduates at the University of Ilorin, Nigeria?

\section{Hypotheses}

1. There is no significant difference in the sources of academic stress among undergraduates at university of Ilorin on the basis of gender.

2. There is no significant difference in the sources of academic stress among undergraduates at University of Ilorin on mode of entry.

3. There is no significant difference in the sources of academic stress among undergraduates at University of Ilorin on the basis of age.

\section{Methodology}

The research design adopted for this study is the descriptive survey method. Stangor (2004) viewed the descriptive survey method as a research approach that focuses on people and their beliefs, opinions, perception, motivations and behaviour. This research, therefore, adopts the descriptive survey research method because it employs the use of a questionnaire in order to determine the opinions, preferences, and perception of persons of interest to the research.

The population for this study comprised all undergraduates at the University of Ilorin, Nigeria. Simple random and stratified sampling techniques were adopted for this study. These were employed because not all undergraduates can participate in the study. Daramola (2006) was of the view that every member in a sample population stands a chance of being selected and that the selection of one member does not affect the other. Therefore, 300 undergraduates were sampled across the faculties. The selected respondents were later stratified based on gender, mode of entry, and age.

The instrument was content validated by lecturers from the Department of Counsellor Education, University of Ilorin, while the test re-test reliability method was used to ascertain the correlation coefficient. A coefficient of 0.82 was obtained which was judged reliable for the study.

The data collected were analyzed using descriptive and inferential statistics. The hypotheses generated were tested using the t-test statistical method at 0.05 level of significance.

\section{Results}

Research Question 1: What are the sources of academic stress among undergraduates at University of Ilorin?

Table 1

Mean and Rank Order on Sources of Academic Stress among Undergraduates at the University of Ilorin

\begin{tabular}{llll}
\hline S/N & The following are some of sources of academic stress among undergraduates & Mean & Rank \\
\hline 1 & Academic overloads & 3.30 & $1^{\text {st }}$ \\
6 & Fear of failure & 3.16 & $2^{\text {nd }}$ \\
8 & acclimatizing to academic expectations & 2.95 & $3^{\text {rd }}$ \\
2 & Time-management & 2.91 & $4^{\text {th }}$ \\
14 & making decisions regarding daily schedules & 2.88 & $5^{\text {th }}$ \\
\end{tabular}




\begin{tabular}{llll}
\hline 16 & Progress report to parent & 2.84 & $6^{\text {th }}$ \\
20 & Unable to discuss Academic failures with parents & 2.84 & $6^{\text {th }}$ \\
7 & Academic punishments & 2.83 & $8^{\text {th }}$ \\
17 & Lack of assertiveness (confidence) in the class & 2.79 & $9^{\text {th }}$ \\
9 & Lecturers fairness & 2.78 & $10^{\text {th }}$ \\
12 & Inadequate resources & 2.77 & $11^{\text {th }}$ \\
11 & Family stressor & 2.76 & $12^{\text {th }}$ \\
4 & Competition with fellow students & 2.73 & $13^{\text {th }}$ \\
13 & Inadequate financial resources & 2.69 & $14^{\text {th }}$ \\
5 & Lateness to do assignments & 2.65 & $15^{\text {th }}$ \\
15 & Extra demand by lecturers & 2.64 & $16^{\text {th }}$ \\
18 & Monotonous (boring or tedious) teaching style by & 2.61 & $17^{\text {th }}$ \\
& the teacher & & \\
10 & Quizzes and exams & 2.58 & $18^{\text {th }}$ \\
19 & Difficulty in public speaking. & 2.53 & $19^{\text {th }}$ \\
3 & Overcrowded lectures hall & 2.50 & $20^{\text {th }}$ \\
\hline
\end{tabular}

Table 1 shows that all the twenty items have means scores not less than 2.50 which is the cut-off point. Items 1 (with a mean score of 3.30), 6 (with a mean score of 3.16) and 8 (with a mean score of 2.95) took precedence over others and were ranked 1st, 2nd and 3rd respectively. The items stated that the following are some of the sources of academic stress among undergraduates: "academic overloads", "fear of failure" and "acclimatizing to academic expectations" respectively.

\section{Hypotheses Testing}

Hypothesis One: There is no significant difference in the sources of academic stress among undergraduates on the basis of gender.

Table 2

The T-test Results Showing a Difference in Respondents' Sources of Academic Stress among Undergraduates on the Basis of Gender

\begin{tabular}{lccccccc}
\hline Gender & N & Mean & SD & df & Cal. t-value & Crit. t-value & p-value \\
\hline Male & 138 & 55.14 & 11.03 & 298 & 1.75 & 1.96 & .08 \\
Female & 162 & 56.47 & 9.99 & & & \\
\hline
\end{tabular}

Table 2 shows that the calculated t-value of 1.75 is less than the critical t-value of 1.96 with a corresponding p-value of .08 which is greater at 0.05 alpha level. This indicates no significant difference; hence, the hypothesis is not rejected.

Hypothesis Two: There is no significant difference in the sources of academic stress among undergraduates based on mode of entry. 
Table 3

The T-test Results Showing a Difference in Respondents' Sources of Academic Stress among Undergraduates based on Mode of Entry

\begin{tabular}{llllllll}
\hline Status & $\mathbf{N}$ & Mean & SD & df & Cal. t-val. & Crit. t-val. & p-value \\
\hline UTME & 182 & 58.78 & 9.06 & 298 & 3.64 & 1.96 & 0.02 \\
Direct & 118 & 55.68 & 7.92 & & & & \\
\hline
\end{tabular}

Table 3 shows that the calculated t-value of 3.64 is greater than the critical t-value of 1.96 at 0.05 alpha level. This indicated that there was a significant difference. Hence, the hypothesis was rejected.

Hypothesis Three: There is no significant difference in the sources of academic stress among undergraduates on the basis of age.

Table 4

The T-test Results Showing a Difference in Respondents' Sources of Academic Stress among Undergraduates on the Basis of Age

\begin{tabular}{lccccccc}
\hline Age & & $\mathbf{N}$ & Mean & SD & df & Cal. t-val. & Crit. t-val. \\
\hline $\begin{array}{l}\text { Below } \\
\text { years }\end{array}$ & $\mathbf{2 5}$ & 189 & 62.81 & 6.42 & 298 & 1.92 & 1.96 \\
$\begin{array}{l}\mathbf{2 5} \\
\text { above }\end{array}$ & years & 111 & 62.64 & 6.86 & & & \\
\hline
\end{tabular}

Table 4 shows that the calculated t-value of 1.92 is less than the critical t-value of 1.96 at 0.05 alpha level. This indicated that there was no significant difference; hence, the hypothesis was not rejected.

\section{Discussion}

The findings of this study revealed that University of Ilorin undergraduates are exposed to a number of different sources of academic stress which include academic overloads, fear of failure, and acclimatizing to academic expectations. This is in line with the findings of Misra and McKean (2000) which revealed that the transition from high school to university is known to disrupt social security, physical comfort and the ability to enjoy gratifying activities for first year students.

Another finding revealed that there was no significant difference in the sources of academic stress among undergraduates on the basis of gender. This means that both male and female undergraduates are experiencing similar sources of stress at the University of Ilorin. 
This finding is in agreement with the study of Misra and McKean (2000) whose findings revealed that each first-year student, regardless of their gender, has to make decisions regarding when and what to do as well as when to study.

Findings revealed that there was a significant difference in the sources of academic stress among undergraduates at University of Ilorin based on mode of entry. This implies that the sources of stress of undergraduates at the University of Ilorin, admitted through UTME, are significantly different than those who obtained admission through direct entry. This can be because direct entry students have had prior institutional experience from their previous post-secondary schools.

Findings also revealed that there was no significant difference in the sources of academic stress among undergraduates on the basis of age. This implies that both young and old undergraduates are not different in their sources of stress. This might be because all undergraduates have the same goal to achieve, irrespective of their age.

\section{Conclusion}

The findings of this study revealed that undergraduates of the University of Ilorin are exposed to various sources of academic stress which include academic overloads, fear of failure, and acclimatizing to academic expectations. There were no significant differences in the sources of academic stress among undergraduates at the University of Ilorin based on gender and age while there was a significant difference in challenges facing newly admitted undergraduates at the University of Ilorin based on mode of entry.

\section{Recommendations}

Based on the findings of the study, it is recommended that:

1. The University Management should make deliberate efforts to ameliorate the problem associated with student accommodations.

2. The Students need to be seriously engaged with academic work outside of the formal lecture periods with assignments to keep them away from distractions.

3. An orientation program should be made compulsory for all newly admitted students and academic development programs introduced for returnees at faculties and departmental levels.

4. School counsellors should ensure the development of students, create adequate awareness, positive attitudes, and improved motivation towards the university system and school environment in general.

5. Counsellors in the University should be involved in any innovative programs created in the school setting. 


\section{References}

Campbell, H. (2006.) Just planning: The art of situated ethical judgment. Journal of Planning Education and Research, 26(1), 92-106.

Daramola, S. O. (2006). Research and statistical method in education for students and researchers in tertiary institutions. Ilorin: Bamitex Printing and Publishers.

Dziegielwski, S. F., Turnage, B. \& Roest-Marti, S. (2004). Addressing stress with social work students: A controlled evaluation. Journal of Social Work Education, 40, 105119.

Fairbrother, K, \& Warn, J. (2003). Workplace dimensions, stress and job satisfaction. $J$. Managerial Psychol. 18(1), 8-21.

Federal Republic of Nigeria (2013). National Policy on Education, Lagos: FRN.

Finlayson, M. (2003). Improving the wellbeing of teachers in Scotland, Scott. Educ. J., 87(1), $18-19$.

Garrett, G. (2001). Globalization and government spending around the world. Studies in Comparative International Development, 35(4), 3-29.

Gibbons, R. M., \& Gibbons, B. (2007). Occupational stress in chef professional. Int. J. Contemp. Hospitality Management, 19, 32-42.

Misra, R., \& McKean, M. (2000). College students' academic stress and its relation to their anxiety, time management, and leisure satisfaction. Am. J. Health Stud. 16(1), 41-51.

McCarty, W. P., Zhao, J.S., \& Garland, B. E. (2007). Occupational stress and burnout between male and female police officers. Are there any gender differences? Policing: Int. J. Police Strateg. Manage. 30(4), 672-691.

Okonigbo, U. E. \& Tugbokorowei, P. T. I. (2015). Adjustment problem of National Diploma student in Burutu environment: A case study of Delta State school of marine technology, Burutu, Delta State. International Journal of Multidisciplinary and Current Research, 489-494.

Ongori H. (2007). A review of the literature on employee turnover. Afri. J. Bus. Manage., $1(3), 49-54$.

Rees, C. J., \& Redfern, D. (2000). Recognising the perceived causes of stress: A training and development perspective. Industrial and Commercial Training, 32, 120-127.

Smith, A. (2002). The scale of perceived occupational stress. Occup. Med., 50, 294-8.

Stangor, C. O. (2004). Research methods for behavioural sciences. Boston: Houghton Mifflin Co. 